\title{
Should development agencies have Official Views?
}

\section{David Ellerman}

The major development agencies have ex cathedra 'Official Views' (with varying degrees of explicitness) on the complex and controversial questions of development. At the same time, knowledge is now more than ever recognised as key to development-in the idea of a 'knowledge bank' or knowledge-based development assistance. The author argues that these two practices are in direct conflict. When an agency attaches its 'brand name' to certain Official Views, then it becomes very difficult for the agency also to be a learning organisation or to foster genuine learning in its clients. A model of a development agency as an open learning organisation, which is in sharp contrast to other organisational models such as the Church or the party, is outlined. That, in turn, allows the agency to take a more autonomycompatible approach to development assistance with the assisted country 'in the driver's seat' of a learning process rather than as the passive recipient of aid-sweetened policies from the agency.

\section{Introduction: a 'Church' or 'party' organisation versus a 'learning organisation'}

In the world today, most organisations want to be seen as 'learning organisations' that emphasise the importance of the accumulation of 'intellectual capital' and 'knowledge management'. Yet many old habits persist that are in direct contradiction to learning and to the advancement of knowledge. Church- or political party-like organisations proselytising their own dogmas apply the new rhetoric of 'learning' as a veneer. (Throughout this article, I use both the 'Church' and 'Communist Party' metaphors to indicate unitary organisations espousing certain 'truths' or messages instead of being engaged in an open-ended search for knowledge.)

Focusing on an organisation or agency involved in knowledge-based development assistance (such as the World Bank) operating as a 'knowledge bank', the main question I seek to address is: how can such an agency function as a learning organisation? I approach this question by first considering some of the major roadblocks in the way of organisational learning before launching into a discussion of the open learning model and how development agencies can become learning organisations. 


\section{Roadblock to learning No. 1: branded knowledge as dogma}

To put it simply, the basic problem is that in spite of the espoused model of a 'learning organisation', the theory-in-use of a development agency is often a model of a 'development church' giving definitive ex cathedra 'views' on the substantive and controversial questions of development. As with the dogmas of a Church, the brand name of the organisation is invested with its views. Once an 'Official View' has been adopted, then to question it is to attack the agency itself and the value of its franchise. As a result, new learning at the expense of established Official Views is not encouraged. Thus when licensing an Official View, the authorities need to have what Milton called the 'grace of infallibility and incorruptibleness' (see Morley 1928:218), since any subsequent 'learning' is tantamount to disloyalty.

When an agency adopts Official Views, then discussions between the agency staff and its clients is a pseudo-dialogue, given that the former are not free unilaterally to change Official Views (just as missionaries are not free to approve local variations in Church dogmas) or to approve of a project that departs substantially from those views. The slogan is something like: 'Give the clients an inch of nuance, and they'll take a mile of status quo' (Kanbur and Vines 2000:101). Clients are like Henry Ford's Model T customers who were free to choose any colour car so long as it was black. The clients who wish to receive assistance are free to 'learn' and to 'make up their own minds' so long as they do so in conformity with Official Views.

There is little motivation for the staff actively to appropriate or understand any deeper rationale for the views since they must espouse the Official Views vis-à-vis the clients in any case. The views are generally not those that individual staff members have decided upon personally based on evidence or argumentation. In project design, the herd instinct takes over. If a manager designs a project in conformity with Official Views and the project fails, then those involved in the project can hardly be blamed for the outcome of their team efforts.

Publicly airing ambivalence or discontent about the Official Views outside the confines of the agency is frowned upon. The reasoning is standard: parents should not argue in front of the children; doctors should not debate in front of the patients. There can be debate inside the party but once a decision is made, then the members must publicly adhere to the party line. The Church or party model fits perfectly with the standard 'dissemination' or transmission-belt methodology of knowledge-based development assistance. The agency believes it holds the best 'knowledge for development' and is to transmit it to the recipients in the developing world through various forms of aid-baited proselytisation.

What is the alternative? The organisation of science provides the paradigm example of an 'ecology of knowledge' where the open and public contestation of ideas and criticism of conjectures is essential and actively encouraged:

Criticism of our conjectures is of decisive importance: by bringing out our mistakes it makes us understand the difficulties of the problem which we are trying to solve. This is how we become better acquainted with our problems, and able to propose more mature solutions: the very refutation of a theory - that is, of any serious tentative solution to our problem-is always a step forward that takes us nearer to the truth... Since none of [the theories] can be positively justified, it is essentially their critical and progressive character-the fact that we can argue about their claim to solve our problems better than their competitors - which constitutes the rationality of science. (Popper 1965:vii)

Another example of the 'ecology of knowledge' is provided by the modern Western university. The university does not set itself up as an arbiter of truth, but as an arena within which contrary theories can be examined and can collide in open debate. As Barrington Moore $\mathrm{Jr}$ has noted, 'among contemporary social arrangements the modern western 
university is the main one that has endeavoured to make intellectual criticism and innovation a legitimate and regular aspect of the prevailing social order' (Moore 1972:91). The organisation does not itself have Official Views or 'messages' on the questions of the dayand thus it does not need a public relations department to monitor and control the propagating of Official Views to the press.

When an agency takes Official Views on complex questions of development and considers its views as branded knowledge, then the genuine collision of adverse opinions and the rule of critical reasoning tend to give way to the rule of authority and bureaucratic reasoning within the hierarchy of the organisation (The 'Soviet Theory of Genetics' based on Trofim Denisovich Lysenko's work is a good example of this). While a sort-of-debate may be 'encouraged' within the agency, the perimeter of that discussion is framed, not coincidentally, by the jurisdiction of organisational authority. Debate should not stray beyond its pale into the public domain where the authorities have no writ. The authorities in the organisation determine 'the Official Views' and tend to shut off or 'embargo' any feedback loops that may call into question those views, thereby diminishing the 'franchise value' of the 'brand name' — not to mention reflecting poorly on the wisdom of the authorities who sanctioned the views in the first place. Learning from errors, which involves changing 'Official Views' and modifying 'branded knowledge', is minimised, so that the organisation tends to function more as a Church- or party-type organisation than as an open learning one-regardless of the espoused theory.

The Church/party model of proselytising directly contradicts autonomous or self-directed learning in the client countries (see below for more on the Socratic rationale for not having Official Views). The standard dissemination or transmission belt methodology inhibits learning in a similar manner. The project manager from the agency wants the clients to 'learn' as long as they learn 'the right thing'. Any genuinely self-directed learning process in the client country may veer off in the 'wrong direction', which the project manager cannot withstand. The project manager would return to headquarters as a failure without a project. Therefore, the flow of knowledge must be carefully managed to prevent the clients from being distracted by alternative views.

\section{Roadblock to learning No. 2: funded assumptions as dogma}

Why is it so necessary for a development agency to take an Official View on the 'One Best Way' to solve a development problem? One common answer is that a development agency is not a university; the agency puts money as loans or grants behind projects based on various assumptions. Since university professors do not 'put their money where their mouth is', they are free to debate questions for ever. Once an agency has committed significant resources to certain assumptions, then it becomes necessary to 'fall in line' and support the funded assumption.

But while there may be obvious bureaucratic reasons why individual project managers and their superiors would like a funded project assumption to be treated as 'gospel', that does not explain why the whole institution should take such a stand. The commitment of funds and prestige even seems to alter perceptions. ${ }^{1}$ For instance, subjective assessments of winning probabilities tend to increase after the bets have been placed at a race track, but horses do not run faster when bets are riding on them. Theories are corroborated by evidence, not by funding commitments. Many businesses have come to grief because managers would not revisit strategies after initial costs were sunk. In view of the record of international development aid (see, for example, Easterly 2001), there is little support for the similar practice of hardening project assumptions into gospel simply because funds have been committed. 


\section{Roadblock to learning No. 3: 'social science' as dogma}

Today, 'science' has long since replaced religious authority as the source of dogmas that one can appeal to without further reasoning or corroboration, even though that line of argumentation completely misrepresents the scientific method, not to mention the role of critical thinking. But the all-too-human factors that previously made Church dogma appealing have not suddenly disappeared in today's scientific age, so one should expect the appeal to 'science' to be thoroughly abused. This is nowhere truer than in the social sciences (see Andreski 1972). Economics is the 'rooster who rules the roost' in the social sciences, so one should expect much to be passed off in the name of 'economics'. Yet many of the theses imposed by bureaucratic power as the 'Truths of Economics' would not pass without serious challenge in any open scientific forum - particularly when one goes beyond academic model building to policy applications. One example that springs to mind is the role in the Russian reform debacle that Harvard economic geniuses and the Western agencies who tried to 'install' the institutions of a market economy played (see Ellerman 2001).

It is particularly unfortunate when a Tayloristic 'One Best Way' (OBW) mentality creeps into development policy making in the name of 'science' (see Kanigel 1997). The problems of developing and transition countries are far too complex to yield to formulaic 'best practices' and 'magic bullets'. Many different approaches need to be tried on an experimental basis, so when a major development agency forsakes experimentalism to stake its reputation on the 'One Best Way', then the development effort as a whole is impoverished.

The idea that a development agency always has to have an Official View (rather than house competing views) is about as scientific as the 'scientific' socialism of the communist parties of the past. John Dewey quotes the English Communist John Strachey's statement that the communist parties' 'refusal to tolerate the existence of incompatible opinions ... [is] simply asserting the claim that Socialism is scientific'. Dewey goes on to comment that it 'would be difficult, probably impossible, to find a more direct and elegantly finished denial of all the qualities that make ideas and theories either scientific or democratic than is contained in this statement' (Dewey 1939:96). Critical reasoning and scientific methodology go in quite the opposite direction of fostering the

willingness to hold belief in suspense, ability to doubt until evidence is obtained; willingness to go where evidence points instead of putting first a personally preferred conclusion; [and the] ability to hold ideas in solution and use them as hypotheses to be tested instead of as dogmas to be asserted... (Dewey 1939:145)

This part of the scientific attitude is translated into the policy domain with such suggestions as multiple advocacy (Haas 1990:210) and double visioning (see Schön 1983:281). But it is not some wanton perversity that prevents this scientific attitude from being implemented in a large organisation such as a major development agency. There are quiet human impulses that push for conformity and rigidity:

To hold theories and principles in solution, awaiting confirmation, goes contrary to the grain. Even today questioning a statement made by a person is often taken by him as a reflection upon his integrity, and is resented. For many millennia opposition to views widely held in a community was intolerable. It called down the wrath of the deities who are in charge of the group ... Baconian idols of the tribe, the cave, the theater, and den have caused men to rush to conclusions, and then to use all their powers to defend from criticism and change the conclusions arrived at. (Dewey 1939:146) 


\section{Roadblock to learning No. 4: the rage to conclude}

Albert O. Hirschman has often noted the problems created in developing countries by the tendency that Flaubert ridiculed as la rage de vouloir conclure, or the rage to conclude (see Hirschman 1973:238-240). The same attitude is rampant in development agencies. Indeed, this is another self-reinforcing lock-in between development agencies and their client countries.

[Policy makers] will be supplied with a great many ideas, suggestions, plans, and ideologies, frequently of foreign origin or based on foreign experience ... Genuine learning about the problem will sometimes be prevented not only by the local policy makers' eagerness to jump to a ready-made solution but also by the insistent offer of help and advice on the part of powerful outsiders ... [S] uch practices [will] tend to cut short that 'long confrontation between man and a situation' (Camus) so fruitful for the achievement of genuine progress in problem-solving. (Hirschman 1973:239-240)

The puzzles that development agencies face about inducing economic and social development are perhaps the most complex and ill-defined questions confronting humankind. Donald Schön (1971, 1983) noted the novel complexity, genuine uncertainty, conflict of values, unique circumstances, and structural instabilities that plague problems of social transformation and preclude definitive blueprint solutions. Yet one must marvel at the tendency of the major development agencies to rush forward with universal 'best practices' ${ }^{2}$ - a tendency based not on any methods resembling social science but on a bureaucratic need to maintain élite prestige by 'having an answer' for the client. In contrast, every field of science is populated by competing theories, and scientists do not feel the need to artificially rush to closure just to 'have an answer'.

Consider, for example, the complex problem of fighting corruption. Economists might approach the topic by trying to minimise government-imposed discretionary regulations which present rent-seeking opportunities to officials who might offer to relax a restriction for appropriate compensation. Accountants might emphasise transparency and uniformity of data and the independence of auditing. Civil servants might emphasise codes of ethics, organisational morale, and disclosure requirements. Lawyers might encourage civil discovery procedures and criminal sanctions. Others will promote a free and independent press, a high standard of public ethics, and a vigorous civil society. There are clearly many ways to approach the topic and so a multi-pronged approach rather than a 'One Best Way' seems advisable. Yet the dogmatic mentality might express alarm and dismay when different groups from the same international development agency take different approaches to fighting corruption and these different views are aired openly. Why can't the international agency 'get its act together' and tell the client the One Best Way to address the problem?

When journalists try to 'build a story' by pointing out differences within a development agency, then agency bureaucrats should point out the necessity of the open clash of adverse opinions to intellectual progress (perhaps with references to Mill's On Liberty or the history of science). They should point out that the real story is the intellectual honesty and integrity of an agency willing to have such open discussions which are the lifeblood of intellectual and scientific progress. Instead, PR-oriented bureaucrats are more typically alarmed at the lack of 'coordination of messages' and re-dedicate themselves to better 'vetting' the public statements of agency officials and researchers, a tragi-comic effort usually carried out in the name of 'quality control'.

The Church/party approach has implications for the question of client-centred versus paternalistic approaches to client learning. What would be 'wrong' with an international development organisation acknowledging, and listeners or readers realising, that reasonable 
people within the same agency may differ on the remarkably complex questions of development? Indeed, such a realisation might have the rather positive effect of encouraging listeners or readers to reflect upon the matter more seriously and thereby take some responsibility in forming their own opinions. ${ }^{3}$ In short, it would foster active learning rather than promoting passive acceptance of the 'truth' promulgated by a Church- or party-like organisation.

Often the argument is that 'Yes, there are doubts and differences within the agency, but the agency must show a united front in order to steel the resolve of the clients trying to implement a difficult programme of social and economic change.' Perhaps the clear resolve of the agency's Official View and the possibility of conditioning aid on the acceptance of that reform package will tip the domestic balance between reform and anti-reform coalitions in a developing country in favour of the former and bring the internal advocates of that view to power. But there are several problems with this line of argument. First, it implicitly assumes a Jacobinic (or market-Bolshevik) rather than an adaptive and experimentalist strategy of change. Indeed, a Jacobin-Bolshevik strategy does assume a fanatical resolve that cannot publicly entertain doubts, but that is one of the many problems with such a philosophy of social change. An adaptive, experimental, or pragmatic approach requires no such certitude and in fact welcomes a variety of parallel experiments in multiple regions or sectors to see what works (the social and economic reforms undertaken in China over the past two decades are a good example of this). Second, this argument assumes that the client is deriving its reform motivation from the agency, and not from within its ranks. Third, while Hirschman notes that this imagined sequence is not impossible, it is our conviction that this picture of program aid as a catalyst for virtuous policies belongs to the realm of rhapsodic phantasy' (1971:205).

\section{The open learning model and autonomy-compatible assistance}

Surely much has been learned about economic development. What is wrong, one might ask, with espousing the best practices from successful development efforts as well as promoting underlying guiding principles? Should international development organisations just be agnostic on the questions of development and treat all opinions as having equal weight? To approach these questions, it is useful to consider the methodology of science. Science as a loosely structured international open learning organisation is hardly agnostic in any given area. All opinions are not given equal weight. Certain theories have so far waged the gauntlet of criticism better than others, so they are accepted as the 'received' or current theories in a field. The difference from a more dogmatic Church- or party-type approach lies in the methodology used to sustain or overturn the hypotheses. In mathematics, it is intersubjectively verifiable proof, not authority, that is the basis for theorems. In the empirical sciences, hypotheses are developed on the basis of intellectual coherence and factual cues, and are then openly subjected to experiments that can be inter-subjectively verified and reproduced (for example, as in the 'cold fusion' controversy). As long as inter-subjective verification remains the touchstone of any scientific theory, then no theory needs, in principle, to be accepted on the basis of authority. Science does not operate on the basis of brand names. Adding the brand name of an agency to a thesis in order to make it an Official View adds nothing of scientific value to the thesis. Indeed, the association of bureaucratic power with the thesis tends to corrupt the operation of critical thinking.

This methodology of science shows, at least in general terms, how an open learning model of a knowledge-based development agency might translate into assistance that is compatible with the autonomy of the client. The important thing is not to teach a client country the 'truth' 
but first to ensure that all major positions on a controversial question are presented, and second (and of greater long-term importance), to foster the active learning methodology within the country in order to find and corroborate or disprove the hypotheses and theories. That means capacity building in the knowledge institutions of the country.

When theories clash then experiments should be encouraged to 'see what works'. Indeed, there are usually different decentralised experiments going on in a country (sometimes called 'moving trains') often unbeknownst to government officials. As Hirschman has noted, 'the hidden rationalities I was after were precisely and principally processes of growth and change already under way in the societies I studied, processes that were often unnoticed by the actors immediately involved, as well as by foreign experts and advisors' (Hirschman 1984:91-93). Where the train of reform is already moving on its own, then reformers can jump on board to attempt to help it run more smoothly. The 'moving trains' can be held up as models and benchmarks for other reform efforts in the country. Everett Rogers (1983:Chapter 9) describes decentralised diffusion systems for social innovations with the primary example being the Chinese system of 'models' (e.g. model communes or enterprises) dating from the beginning of the modern reform period in the 1970s and forming an important part of the most remarkable growth episode in history (the 'Chinese economic miracle' of the 1980s and 1990s).

For instance, if a knowledge-based development agency wants to promote the OBW of reforming or changing certain institutions (e.g. the 'best' model for fighting corruption or the 'best' form of privatisation), then it should be willing to share the source of that 'knowledge', to promote experiments to corroborate hypotheses or to validate a local adaptation, and to encourage horizontal cross-learning from similar experiments documented in the organisation's knowledge management system - all before the reform is accepted as a 'blueprint' for any country as a whole. In short, the inter-subjectivity and reproducibility that are key to scientific knowledge translate into local experimentation and verification in the case of development knowledge. The message to policy makers should run along these lines:

To the best of our accumulated experience (which we deem to call 'knowledge'), here is what works best in countries like yours. Why don't you study these principles together with their corroboration to date (best practice success stories), take a look at these case studies, contact the people who designed those reforms, set up horizontal learning programmes with those best practice cases, and try some experiments to see what works in various parts of your own country? After carrying out this learning process on your own, you might call us back if you feel we could help by partially but not wholly funding the reform programme you have decided upon.

The most important thing is to get away from a paternalistic model of 'teaching' as the transmission of knowledge from the development agency to the developing country. Using the slogan, 'Stop the teaching so that the learning can begin!', Ortega y Gasset suggested: 'He who wants to teach a truth should place us in the position to discover it ourselves' (1961:67). To impose a model without this local learning process would be to short-circuit and bypass the active learning capability of local policy makers, to substitute authority in its place, and thus to perpetuate the passivity of tutelage. ${ }^{4}$

If the development agency can move beyond the Church or party model to an open learning model, then it can also move from standard knowledge dissemination or transmission-belt methodology towards knowledge-based capacity building:

The aim of teaching is not only to transmit information, but also to transform students from passive recipients of other people's knowledge into active constructors of their own 
and others' knowledge. The teacher cannot transform without the student's active participation, of course. Teaching is fundamentally about creating the pedagogical, social, and ethical conditions under which students agree to take charge of their own learning, individually and collectively. (Elmore 1991:xvi)

This form of activist pedagogy adapted to developing countries (as active learners) would constitute autonomy-enhancing knowledge-based development assistance.

\section{Competition and devil's advocacy in the open learning model}

How can a large bureaucratic agency itself advance from the Church or party model towards an open learning model? One way is for the agency to foster competition in a market-place for ideas internally - something which requires an open ecology of knowledge and criticism, not the closed system of Official Views. This is expressed in the 'market-place of ideas conceptthe proposition that truth naturally overcomes falsehood when they are allowed to compete... The belief that competing voices produce superior conclusions [is] ... implicit in scientific reasoning, the practice of trial by jury, and the process of legislative debate' (Smith 1988:31). For instance, the defendant's right to an attorney in a US courtroom takes away from the prosecutor the monopoly right to present evidence and arguments. A judge may not go to the jury before both sides of the arguments have been heard, and a patient should not go to surgery before getting a second opinion. Even the Roman Catholic Church, when considering someone for sainthood, has a 'devil's advocate' (Advocatus Diaboli) to state the other side of the story. A development agency should not pretend to greater authority or infallibility when it canonises a good practice success story as the OBW.

This idea of the constructive role of public criticism goes back at least to the time of Socrates in Athens:

For if you kill me you will not easily find a successor to me, who, if I may use such a ludicrous figure of speech, am a sort of gadfly, attached to the state by God; and the state is a great and noble horse who is rather sluggish owing to his very size, and requires to be stirred into life. I am that gadfly which God has attached to the state, and all day long and in all places am always fastening upon you, arousing and persuading and reproaching you. (Plato 1997:30-31)

The penchant for competition seems to be one of the key features of Athenian Greece that distinguished it from other societies of antiquity, and Socrates represented the use of dialogue and contestation as the road to improving knowledge. 'The form Socrates' teaching tookintellectual duelling before a sportive audience-looks much odder to us than it did to Athenians, whose whole culture was based on the contest (agon), formal and informal, physical, intellectual, and legal' (Wills 1994:163). Immanuel Kant recognised that the 'means which nature employs to bring about the development of innate capacities is that of antagonism within society', and he portrayed the insight with the analogy of trees competing in a forest:

In the same way, trees in a forest, by seeking to deprive each other of air and sunlight, compel each other to find these by upward growth, so that they grow beautiful and straight-whereas those which put out branches at will, in freedom and in isolation from others, grow stunted, bent and twisted. All the culture and art which adorn mankind and the finest social order man creates are fruits of his unsociability. (Kant 1991:46) 
Of course, not all antagonism or unsociability is helpful, and Hirschman (1995) has investigated which forms of social conflict are more beneficial than others (see also Coser 1956), a question that also goes back to the contrast between Socrates' use of provocative dialogues to improve knowledge and the Sophists' eristic methods employed simply to defeat an opponent.

For our purposes, however, the focus is on the difference between an organisation that incorporates (one hopes, beneficial) antagonism and one that aims at a non-antagonistic idea of agreement, cooperation, and 'team play' — a small society like that dryly satirised by Kant as the Arcadian ideal where men would be 'as good-natured as the sheep they tended' (Kant 1991). Some modern research (Lloyd 1996) has used this contrast to address the question of why, after such promising beginnings in ancient China, science developed so strongly in ancient Greece did not develop further in China. The key feature in ancient China was the intermix of power with the desire to answer questions of empirical truth - a feature shared by the Church during the Middle Ages or by Lysenkoism (and the role of the party in general) in the Soviet Union. In ancient China, the emperor's Mandate of Heaven was based on a view of the world that pictured the emperor in the central role of maintaining harmony between heaven and earth, and the views of philosophers and scientists needed to accommodate that basic scheme. By contrast, Greek intellectual life exhibited 'radical revisability' (Lloyd 1996:216) where thinkers would offer theories completely at odds with those of their rivals. Chinese intellectual life emphasised accommodation and harmony while the Greeks thrived on antagonism and adversarial clashes. The differences extended throughout social and legal affairs:

Differences between individuals or groups that might well have been the subject of appeal to litigation in Greece were generally settled [in China] by discussion, by arbitration, or by the decision of the responsible officials. The Chinese had, to be sure, no experience that remotely resembled that of the Greek dicasts [large public juries], nor, come to that, that of Greek public participation in open debate of political issues in the Assemblies. (Lloyd 1996:109)

Given the rather clear historical verdict of the mixing of power and knowledge in ancient China, the medieval Church, and more recently the Communist Party, there seems to be little basis for a development agency dedicated to promoting development knowledge to adopt 'Official Views' on some of the most complex and subtle questions facing humankind.

Aside from not licensing Official Views, how might an agency promote internal adversarial engagement? Devil's advocacy is one practice that might be fostered in a development agency functioning as an open learning organisation. ${ }^{5}$ The political scientist Alfred De Grazia recommends such a countervailing system as a part of any large bureaucracy: 'The countervailors would be a corps of professional critics of all aspects of bureaucracy who would be assigned by the representative council of an institution to specialise as critic of all the subinstitutions' (De Grazia 1975). Devil's advocacy might provide a constructive alternative in addition to negative criticism of the proposed policy. In economics, the opportunity cost doctrine evaluates an option by comparing its value to the value of a best alternative. If plan $\mathrm{B}$ is the best alternative to plan A (and the plans are mutually exclusive), then the opportunity cost of choosing plan A is the value foregone by not choosing plan B. Plan A is preferable if its value exceeds its opportunity cost (assuming both can be quantitatively measured). The application of the opportunity cost doctrine requires the analysis and evaluation of the best alternative-and that is the more general role of devil's advocacy even when quantitative values are not available. By eliciting plan B, devil's advocacy generalises the opportunity cost doctrine from cost-benefit analysis to general policy analysis. Just as in an open market 
competition provides the B plans, organisational devil's advocacy could be seen as an attempt to provide benchmark competition within an organisation.

The general case for a more systematic devil's advocate or countervailing role in an organisation is much the same as the case for genuine debate and open discussion. One classic statement of that argument can be found in John Stuart Mill's 1859 essay On Liberty. If little is known on a question, then real debate and the 'clash of adverse opinions' are some of the best engines of discovery. If 'partial truths' are known, then the same is necessary to ferret out a clearer picture and to better adapt theories to new and different contexts. Mill argued that even in cases of settled opinions, debate and discussion serve to disturb the 'deep slumber of a decided opinion' so that it might be held more as a rational conviction than as an article of faith:

So essential is this discipline to a real understanding of moral and human subjects, that if opponents of all important truths do not exist, it is indispensable to imagine them, and supply them with the strongest arguments which the most skilful devil's advocate can conjure up. (Mill 1972:105)

\section{Non-dogmatism and Socratic ignorance in organisations}

I have argued that organisational learning can best take place if open competition, devil's advocacy, and the collision of ideas are fostered instead of being suppressed in favour of an outward show of allegiance to Official Views. This openness is now taken for granted in the institutions of higher learning as well as in the informal communities of the sciences, but many development agencies still operate on the basis of the Church or party model, regardless of the espoused theory.

I now turn from these competition- or rivalry-based arguments to a different type of argument against having Official Views in an organisation that aspires to be a learning organisation and to foster learning in its clients. How can the development agency help the client 'own' the knowledge being acquired? The helper needs to refrain from trying to teach or impose a certain representation or view on the doers. ${ }^{6}$ That will call for the helper to display non-assertiveness, non-dogmatism, cognitive humility, ${ }^{7}$ tolerance, 'egolessness' (Davenport and Prusak 1998:113), or Socratic ignorance. ${ }^{8}$ This Socratic humility or ignorance is the cognitive counterpart to the forbearance of the type of material assistance that would create dependency and undercut the volition of self-help on the part of the doers. As George Bernard Shaw put it: 'if you teach a man anything he will never learn it' (Winsten 1962:174).

Thus even if an agency has the 'answer' (and that is a big 'if'), it should still refrain from 'teaching' it (not to mention enforce its 'learning' through aid conditionalities). It should engage in capacity building and facilitating the doers' own learning process, and not in trying to 'teach' or 'disseminate' what it takes to be the answers. Paulo Freire made this point about development professionals working with people in a community:

Whatever the specialty that brings [the professionals] into contact with the people, they are almost unshakably convinced that it is their mission to 'give' the latter their knowledge and techniques. They see themselves as 'promoters' of the people. Their programs of action ... include their own objectives, their own convictions, and their own preoccupations. They do not listen to the people, but instead plan to teach them how to 'cast off the laziness which creates underdevelopment'. . They feel that the ignorance of the people is so complete that they are unfit for anything except to receive the teachings of the professionals. (Freire 1970:153-154) 
For an example closer to home, upon seeing a child struggling with a homework problem parents may feel the urge to just supply what they think is the answer, but parents also presumably know they should resist that urge as it would undercut the learning process. Why do development agencies find it so difficult to apply the same principle?

\section{Disclaimer}

The views, findings, interpretations, and conclusions expressed in this paper are entirely those of the author and should not be attributed in any manner to the World Bank, its affiliated organisations, the members of its Board of Directors, or the countries they represent.

\section{Notes}

1 When predictions fail, then skewed perceptions and rationalisations are a likely outcome. See Festinger (1957) and Elster (1983). See Akerlof and Dickens (1982) for an economic treatment of cognitive dissonance.

2 The universal suggestion that everyone should wear a three-piece suit still requires local tailoring or adaptation to each person's size and shape. This illustrates the fallacy in the argument that an agency does not recommend a 'universal recipe' simply because it explicitly recognises the need for local adaptation.

3 Some of the best computer-based training programmes have 'experts' popping up on the screen giving contradictory advice. 'In other words, the program communicates that there's not always one right answer. It invites trainees to learn to use their own judgement rather than rely on someone else's-especially when the someone else isn't as close to the situation as you are. Organisations today are facing increasingly complex situations where there are many possible answers. Traditional training that insists on right and wrong answers disempowers the individual-it robs people of their decision-making ability' (Schank 1997:24).

4 In 1784, Immanuel Kant wrote a short but influential pamphlet What is Enlightenment? Enlightenment, he wrote, 'is man's release from his self-incurred tutelage. Tutelage is man's inability to make use of his understanding without direction from another. Self-incurred is this tutelage when its cause lies not in lack of reason but in lack of resolution and courage to use it without direction from another. Sapere aude! "Have the courage to use your own reason!" - that is the motto of enlightenment' (see Schmidt 1996; see also Ellerman 1999 on these issues).

5 Devil's advocacy (see Schwenk 1984) is interpreted broadly to include a number of related techniques to better elicit the main policy alternatives. A Cassandra's advocate (Janis 1972:217) is a person who emphasises alternative interpretations of data and focuses on all the things that can go wrong ('Murphy's Law-yer'). The Rashomon effect (see Schön 1971:210) illustrates that the same set of circumstances and events can be interpreted very differently by different people.

6 The Socratic-Kantian Leonard Nelson emphasises this aspect of the Socratic process of instruction: 'Philosophical instruction fulfills its task when it systematically weakens the influences that obstruct the growth of philosophical comprehension and reinforces those that promote it. Without going into the question of other relevant influences, let us keep firmly in mind the one that must be excluded unconditionally: the influence that may emanate from the instructor's assertions. If this influence is not eliminated, all labor is vain. The instructor will have done everything possible to forestall the pupil's own judgement by offering him a ready-made judgement' (Nelson 1949:19). 
7 'But all true effort to help begins with self-humiliation: the helper must first humble himself under him he would help, and therewith must understand that to help does not mean to be a sovereign but to be a servant, that to help does not mean to be ambitious but to be patient, that to help means to endure for the time being the imputation that one is in the wrong and does not understand what the other understands' (Kierkegaard, quoted in Bretall 1946:334).

8 'True Socraticism represents first and foremost an attitude of mind, an intellectual humility easily mistaken for arrogance, since the true Socratic is convinced of the ignorance not only of himself but of all mankind. This rather than any body of positive doctrine is the contribution of Socrates' (Guthrie 1960:75).

\section{References}

Akerlof, George and William Dickens (1982) 'The economic consequences of cognitive dissonance', American Economic Review 72 (June):307-319.

Andreski, Stanislav (1972) Social Sciences as Sorcery, New York, NY: St. Martin's Press. Bretall, Robert (ed.) (1946) A Kierkegaard Anthology, Princeton, NJ: Princeton University Press.

Coser, Lewis (1956) The Functions of Social Conflict, New York, NY: Free Press.

Davenport, Thomas and Laurence Prusak (1998) Working Knowledge, Boston, MA: Harvard Business School Press.

De Grazia, Alfred (1975) Eight Bads-Eight Goods: The American Contradictions, Garden City, NY: Anchor Books.

Dewey, John (1939) Freedom and Culture, New York, NY: Capricorn.

Easterly, William (2001) The Elusive Quest for Growth: Economists' Adventures and Misadventures in the Tropics, Cambridge, MA: MIT Press.

Ellerman, David (1999) 'Global institutions: transforming international development agencies into learning organisations', Academy of Management Executives 13(1):25-35.

Ellerman, David (2001) 'Lessons from East Europe's voucher privatisation', Challenge: The Magazine of Economic Affairs 44(4):14-37.

Elmore, R. (1991) Foreword, in C. R. Christensen, D. A. Garvin and A. Sweet (eds.) Education for Judgement, Boston, MA: Harvard Business School Press.

Elster, Jon (1983) Sour Grapes: Studies in the Subversion of Rationality, Cambridge: CUP.

Festinger, L. (1957) A Theory of Cognitive Dissonance, Stanford, CA: Stanford University Press.

Freire, Paulo (1970) Pedagogy of the Oppressed, New York, NY: Continuum.

Guthrie, W. K. C. (1960) The Greek Philosophers: From Thales to Aristotle, New York, NY: Harper \& Row.

Haas, E. B. (1990) When Knowledge is Power: Three Models of Change in International Organisations, Berkeley, CA: University of California.

Hirschman, Albert O. (1971) A Bias for Hope: Essays on Development and Latin America, New Haven, CT: Yale University Press.

Hirschman, Albert O. (1973) Journeys Toward Progress, New York, NY: Norton.

Hirschman, Albert O. (1984) 'A dissenter's confession: "The Strategy of Economic Development” revisited', in G. Meier and D. Seers (eds.) Pioneers in Development, New York, NY: OUP.

Hirschman, Albert O. (1995) Development Projects Observed, Washington, DC: The Brookings Institution.

Janis, I. L. (1972) Victims of Groupthink, Boston, MA: Houghton Mifflin. 
Kanbur, Ravi and David Vines (2000) 'The World Bank and poverty reduction: past, present and future', in C. Gilbert and D. Vines (eds.) The World Bank: Structure and Policies, Cambridge: CUP.

Kanigel, Robert (1997) The One Best Way: Frederick Winslow Taylor and the Enigma of Efficiency, New York, NY: Viking.

Kant, Immanuel (1991, orig. 1784) 'Idea for a Universal History with a Cosmopolitan Purpose', in H. Reiss, Kant: Political Writings, New York, NY: CUP.

Lloyd, Geoffrey Ernest Richard (1996) Adversaries and Authorities: Investigations into Ancient Greek and Chinese Science, Cambridge: CUP.

Mill, John Stuart (1972, orig. 1859) On Liberty, in H. B. Acton (ed.) J.S. Mill: Utilitarianism, On Liberty and Considerations on Representative Government, London: Dent.

Moore Jr, Barrington (1972) Reflections on the Causes of Human Misery and upon Certain Proposals to Eliminate Them, Boston, MA: Beacon Press.

Morley, John (1928) On Compromise, London: Macmillan.

Nelson, Leonard (1949) Socratic Method and Critical Philosophy, New York, NY: Dover.

Ortega y Gasset, José (1961) Meditations on Quixote, New York, NY: Norton.

Plato (1997) Apology of Socrates, Warminster: Arias \& Phillips.

Popper, Karl (1965) Conjectures and Refutations: The Growth of Scientific Knowledge, New York: Harper \& Row.

Rogers, Everett (1983) Diffusion of Innovations, 3rd edn, New York, NY: Free Press.

Schank, Roger (1997) Virtual Learning: A Revolutionary Approach to Building a Highly Skilled Workforce, New York, NY: McGraw-Hill.

Schmidt, J. (ed.) (1996) What is Enlightenment? Eighteenth-century Answers and Twentiethcentury Questions, Berkeley, CA: University of California Press.

Schön, Donald (1971) Beyond the Stable State, New York, NY: Norton.

Schön, Donald (1983) The Reflective Practitioner: How Professionals Think in Action, New York, NY: Basic Books.

Schwenk, C. R. (1984) 'Devil's Advocacy in Managerial Decision Making', Journal of Management Studies 21 (April):153-168.

Smith, Jeffery A. (1988) Printers and Press Freedom: The Ideology of Early American Journalism, New York, NY: OUP.

Wills, Garry (1994) Certain Trumpets: The Call of Leaders, New York, NY: Simon \& Schuster.

Winsten, Stephen (ed.) (1962) The Wit and Wisdom of Bernard Shaw, New York, NY: Collier.

\section{The author}

David Ellerman is currently Economic Advisor to the Chief Economist at the World Bank, where he has focused on issues of labour, capacity building, transition economies, and privatesector development. He was also adviser and speech-writer to the previous Chief Economist Joseph Stiglitz and is the author of numerous books and papers on economic democracy. Contact details: World Bank, Mail Stop MC4-404, 1818 H St NW, Washington, DC 20433, USA. <Dellerman@worldbank.org >; www.ellerman.org 